medRxiv preprint doi: https://doi.org/10.1101/2021.06.12.21258831; this version posted June 15, 2021. The copyright holder for this preprint (which was not certified by peer review) is the author/funder, who has granted medRxiv a license to display the preprint in perpetuity.

It is made available under a CC-BY-NC-ND 4.0 International license .

\title{
Efficacy and safety of hydroxychloroquine as pre-and post-exposure prophylaxis and treatment of COVID-19. Systematic review and meta- analysis of blinded, placebo-controlled, randomized clinical trials.
}

Paulo Ricardo Martins-Filho ${ }^{1,2}$, Lis Campos Ferreira ${ }^{2,3}$, Luana Heimfarth ${ }^{4}$, Adriano Antunes de Souza Araújo ${ }^{2,5}$, Lucindo José Quintans-Júnior ${ }^{2,4}$

1 Investigative Pathology Laboratory, Federal University of Sergipe, Aracaju, Sergipe, Brazil.

2 Health Sciences Graduate Program, Federal University of Sergipe, Aracaju, Sergipe, Brazil.

3 Department of Medicine, Tiradentes University, Aracaju, Sergipe, Brazil.

4 Laboratory of Neuroscience and Pharmacological Assays, Department of Physiology, Federal University of Sergipe, São Cristovão, Sergipe, Brazil.

5 Laboratory of Pharmaceutical Assays and Toxicity, Department of Pharmacy, Federal University of Sergipe, São Cristovão, Sergipe, Brazil.

Address for correspondence: Prof. Paulo Ricardo Martins-Filho. Universidade Federal de Sergipe, Hospital Universitário, Laboratório de Patologia Investigativa. Rua Cláudio Batista, s/n. Sanatório. Aracaju, Sergipe, Brasil. CEP: 49060-100. Email: prmartinsfh@gmail.com 
medRxiv preprint doi: https://doi.org/10.1101/2021.06.12.21258831; this version posted June 15, 2021. The copyright holder for this preprint

(which was not certified by peer review) is the author/funder, who has granted medRxiv a license to display the preprint in perpetuity.

It is made available under a CC-BY-NC-ND 4.0 International license .

\begin{abstract}

\section{BACKGROUND}

Hydroxychloroquine ( $\mathrm{HCQ}$ ) is an anti-malarial and immunomodulatory drug considered a potential candidate for drug repurposing in COVID-19 due to their in vitro antiviral activity against SARS-CoV-2. Despite the potential antiviral effects and anti-inflammatory profile, the results based on clinical studies are contradictory and the quality of the decision-making process from meta-analyses summarizing the available evidence selecting studies with different designs and unblinded trials is limited. The aim of this study was to synthesize the best evidence on the efficacy and safety of HCQ as pre-and post-exposure prophylaxis and treatment of non-hospitalized and hospitalized patients with COVID-19.
\end{abstract}

\title{
METHODS
}

Searches for studies were performed in PubMed, Web of Science, Embase, Lilacs, the website ClinicalTrials.gov and the preprint server medRxiv from January 1, 2020 to May 17, 2021. The following elements were used to define eligibility criteria: (1) Population, individuals at high-risk of exposure to SARSCoV-2 (pre-exposure), individuals who had close contact with a positive or probable case of COVID-19 (postexposure), non-hospitalized patients with COVID-19 and hospitalized patients with COVID-19; (2) Intervention, HCQ; (3) Comparison, placebo; (4) Outcomes: incidence of SARS-CoV-2 infection, need for hospitalization, length of hospital stay, need for invasive mechanical ventilation (MV), death, and adverse events; and (5) Study type, blinded, placebo-controlled, randomized clinical trials (RCTs). Risk of bias was judged according to the Cochrane guidelines for RCTs. Treatment effects were reported as relative risk (RR) for dichotomous variables and mean difference (MD) for continuous variables with 95\% confidence intervals $(\mathrm{Cl})$. We used either a fixed or random-effects model to pool the results of individual studies depending on the presence of heterogeneity. The GRADE system was used to evaluate the strength of evidence between use of HCQ and the outcomes of interest.

\section{RESULTS.}

Fourteen blinded, placebo-controlled RCTs were included in the meta-analysis. Four trials used HCQ as a prophylactic medication pre-exposure to COVID-19, two as a prophylactic medication post-exposure to COVID-19, three as treatment for non-hospitalized patients, and five as treatment for hospitalized patients with COVID-19. We found no decreased risk of SARS-CoV-2 infection among individuals receiving $\mathrm{HCQ}$ as pre-exposure $(\mathrm{RR}=0.90 ; 95 \% \mathrm{Cl} 0.46$ to 1.77 ) or post-exposure ( $\mathrm{RR}=0.96 ; 95 \% \mathrm{Cl} 0.72$ to 1.29$)$ prophylaxis to prevent COVID-19. There is no decreased risk of hospitalization for outpatients with SARS-CoV-2 infection ( $R R=0.64 ; 95 \% \mathrm{Cl} 0.33$ to 1.23$)$ and no decreased risk of $\mathrm{MV}(\mathrm{RR}=0.81 ; 95 \% \mathrm{Cl} 0.49$ to 1.34$)$ and death ( $R R=1.05 ; 95 \% \mathrm{Cl} 0.62$ to 1.78$)$ among hospitalized patients with COVID-19 receiving HCQ. The certainty of the results on the lack of clinical benefit for HCQ was rated as moderate. Moreover, our results demonstrated an increased risk for any adverse events and gastrointestinal symptoms among those using $\mathrm{HCQ}$.

\section{CONCLUSION}

Available evidence based on the results of blinded, placebo-controlled RCTs showed no clinical benefits of $\mathrm{HCQ}$ as pre-and post-exposure prophylaxis and treatment of non-hospitalized and hospitalized patients with COVID-19.

Key-words: Hydroxychloroquine, COVID-19, SARS-CoV-2 infection. 
medRxiv preprint doi: https://doi.org/10.1101/2021.06.12.21258831; this version posted June 15, 2021. The copyright holder for this preprint (which was not certified by peer review) is the author/funder, who has granted medRxiv a license to display the preprint in perpetuity.

It is made available under a CC-BY-NC-ND 4.0 International license .

\section{INTRODUCTION}

Chloroquine (CQ) and hydroxychloroquine ( $\mathrm{HCQ}$ ) are anti-malarial and immunomodulatory drugs that have been suggested for the prevention and treatment of coronavirus disease 2019 (COVID19) due to their in vitro antiviral activity against the severe acute respiratory syndrome coronavirus-2 (SARS-CoV-2) $)^{1,2}$ and the potential for suppressing the release of proinflammatory cytokines. ${ }^{3}$ On March 20, 2020, promising results of HCQ in clearing viral nasopharyngeal carriage of SARS-CoV-2 in hospitalized patients with COVID-19 were described in a small open-label nonrandomized clinical trial (RCT). ${ }^{4}$ These drugs are characterized as diprotic weak bases and can elevate endolysosomal $\mathrm{pH}$ inhibiting the virus/cell membrane fusion. ${ }^{5}$ Despite the potential antiviral effects and anti-inflammatory profile, the results based on clinical studies for patients with COVID-19 are contradictory and an increased risk for severe adverse events has been found for those treated with HCQ. ${ }^{6}$

Recent meta-analyses pooling results of open-label and blinded clinical trials have shown no clinical benefit of anti-malarial drugs on prophylaxis ${ }^{7}$ and treatment of COVID-19. ${ }^{8}$ Contrasting findings were described in a meta-analysis of clinical reports that showed improvement in clinical and virological outcomes for patients using CQ. ${ }^{9}$ Moreover, an evidence synthesis based on observational studies found a $7 \%$ to $33 \%$ reduced mortality in hospitalized patients with COVID19 using lower doses of $\mathrm{HCQ} .{ }^{10}$ Facing the inconsistent evidence on the effects of $\mathrm{HCQ}$ to prevent and treat COVID-19 and the increased risk of adverse events, the World Health Organization (WHO) has not recommended the use of HCQ in COVID-19 ${ }^{11}$. Although the lack of rigorous evidence for efficacy, the politicization of the COVID-19 treatment in some countries and scientific denial have been important factors in promoting interest in use of this drug. ${ }^{12}$

The best evidence synthesis to assess treatment effects can be obtained through the identification, critical appraisal, and summary of results from blinded, placebo-controlled RCTs considered the gold standard in clinical research. Summarizing the available evidence selecting studies with different designs and unblinded trials may compromise the validity of the metaanalysis and the quality of the decision-making process. The aim of this study was to synthesize the best evidence on the efficacy and safety of $\mathrm{HCQ}$ as pre-and post-exposure prophylaxis and treatment of non-hospitalized and hospitalized patients with COVID-19. 
medRxiv preprint doi: https://doi.org/10.1101/2021.06.12.21258831; this version posted June 15, 2021. The copyright holder for this preprint (which was not certified by peer review) is the author/funder, who has granted medRxiv a license to display the preprint in perpetuity.

It is made available under a CC-BY-NC-ND 4.0 International license .

\section{METHODS}

\subsection{Search strategy}

Searches for studies were performed in PubMed, Web of Science, Embase, Lilacs, the website ClinicalTrials.gov and the preprint server medRxiv from January 1, 2020 to May 17, 2021. The search was limited to studies published in full-text versions, without language restriction. In the ClinicalTrials.gov, only completed studies with results were analyzed. The reference lists of all eligible studies and reviews were scanned to identify additional studies for inclusion. The structured search strategies used for each database with specific filters and grey-literature were detailed in the supplementary file.

\subsection{Study selection and eligibility criteria}

Two reviewers (P.R.M.-F. and L.C.F.) independently screened the search results and identified studies that were potentially relevant based on their title and abstract. Relevant studies were read in full and selected according to eligibility criteria. Disagreements between the two reviewers were resolved by consensus.

The following elements were used to define eligibility criteria:

(1) Population: Individuals at high-risk of exposure to SARS-CoV-2 (pre-exposure), individuals who had close contact with a positive or probable case of COVID-19 (post-exposure), nonhospitalized patients with COVID-19 and hospitalized patients with COVID-19.

(2) Intervention: HCQ. Trials that tested drug associations were excluded.

(3) Comparison: Placebo.

(4) Outcomes:

- Pre- and post-exposure prophylaxis: incidence of SARS-CoV-2 infection and any adverse events.

- Non-hospitalized patients with COVID-19: need for hospitalization, death, and any adverse events.

- Hospitalized patients with COVID-19: length of hospital stay, need for invasive mechanical ventilation (MV), death, and any adverse events.

(5) Study type: blinded, placebo-controlled, RCTs. Eligible studies must report at least 1 of the outcomes of interest. Potential overlapping populations, open-label trials, and observational studies were excluded. 
medRxiv preprint doi: https://doi.org/10.1101/2021.06.12.21258831; this version posted June 15, 2021. The copyright holder for this preprint (which was not certified by peer review) is the author/funder, who has granted medRxiv a license to display the preprint in perpetuity.

It is made available under a CC-BY-NC-ND 4.0 International license .

\subsection{Data extraction}

Two authors (P.R.M.-F. and L.C.F.) extracted the data from included studies and crosschecked them for accuracy. Using a standardized data extraction sheet, the following information were extracted from the studies: registry of study protocol, demographic characteristics of study participants, pre-existing medical conditions, treatment arms, HCQ protocol, concomitant medications, follow-up duration, and outcome data. We also extracted data on serious adverse events, QTc interval $>500 \mathrm{~ms}$ and other cardiac manifestations, gastrointestinal symptoms (vomiting, diarrhea, and abdominal pain), skin reaction (rash), headache, and neurologic reactions (irritability, dizziness, vertigo, and seizures).

\subsection{Risk of bias assessment}

Risk of bias was judged according to the Cochrane guidelines for RCTs. ${ }^{13}$ The following domains were evaluated: sequence generation and allocation concealment (selection bias), blinding of participants and personnel (performance bias), blinding of outcome assessment (detection bias), incomplete outcome data (attrition bias), selective outcome reporting (reporting bias), sample size calculation, power analysis, and early stopping for futility (operational bias), outcome measurements (information bias), and the authors' financial or non-financial conflicts of interest that could appear to affect the judgment of research team when designing, conducting, or reporting study. Self-reported diagnosis of COVID-19 was classified as a high risk of information bias. Studies using real-time reverse transcription polymerase chain reaction (RT-PCR) to detect SARS-CoV-2 or, if testing was limited, provided a clinical diagnosis based on COVID-19-related symptoms and epidemiological data were considered as having a low risk of bias.

\subsection{Data synthesis}

Treatment effects were reported as relative risk (RR) for dichotomous variables (incidence of SARS-CoV-2 infection, need for hospitalization, need for MV, death, and adverse events) and mean difference (MD) for continuous variables (length of hospital stay) with 95\% confidence intervals (CI). To calculate MD, means and standard deviations (SD) were obtained for each study group. If the means and SD were not directly reported in the publication, indirect methods of extracting estimates were used. ${ }^{14} \mathrm{~A}$ negative effect size indicated that $\mathrm{HCQ}$ was beneficial in reducing the length of stay for hospitalized patients with COVID-19. To calculate the RR, the 
medRxiv preprint doi: https://doi.org/10.1101/2021.06.12.21258831; this version posted June 15, 2021. The copyright holder for this preprint (which was not certified by peer review) is the author/funder, who has granted medRxiv a license to display the preprint in perpetuity.

It is made available under a CC-BY-NC-ND 4.0 International license .

number of events and individuals in each treatment group were extracted. For studies using three or more different dosages of $\mathrm{HCQ}$, we combined all treatment groups to a single large group.

We used either a fixed or random-effects model to pool the results of individual studies depending on the presence of heterogeneity. Statistical heterogeneity was quantified by the $\mathrm{I}^{2}$ index using the following interpretation: $0 \%$, no between-study heterogeneity; $<50 \%$, low heterogeneity; 50-75\%, moderate heterogeneity; > 75\%, high heterogeneity. ${ }^{15}$ In the case of heterogeneity, we used the random-effects model, otherwise, the fixed-effects model was used. The results of the meta-analysis for each outcome were presented according to the population characteristics and therapeutic proposal (pre-exposure prophylaxis, post-exposure prophylaxis, treatment of non-hospitalized individuals and treatment of hospitalized individuals). We also provided an additional analysis on the overall risk for any and serious adverse events, QTc interval $>500 \mathrm{~ms}$ and other cardiac manifestations, gastrointestinal symptoms, skin rash, headache, and neurologic reactions for individuals receiving $\mathrm{HCQ}$.

Although funnel plots may be useful tools in investigating small study effects in meta-analyses, they have limited power to detect such effects when there are few studies. ${ }^{16}$ Therefore, because we had only a small number of included studies according to the population characteristics and use of $\mathrm{HCQ}$, we did not perform a funnel plot analysis. Forest plots were used to present the effect sizes and the $95 \% \mathrm{Cl}$, and a 2-tailed $p<0.05$ was used to determine significance. Analyses were conducted using Review Manager, version 5.3 (Cochrane IMS).

\subsection{Grading the strength of evidence}

We graded the strength of evidence for the association between use of HCQ and the outcomes of interest as high, moderate, low, or very-low using the Grading of Recommendations Assessment, Development, and Evaluation (GRADE) rating system. ${ }^{17,18}$ In the GRADE system, RCTs begin as high-quality evidence but may be downrated according to the risk of bias assessment, inconsistency, indirectness, imprecision in the results, and publication bias. ${ }^{19}$ Certainty is uprated for estimates with large $(R R>2.0$ or $R R<0.5)$ or very-large $(R R>5.0$ or $R R<0.2)$ magnitude of effect.

Quality of evidence was lowered when the proportion of information from studies at high risk of bias was sufficient to affect the interpretation of results. Evidence of inconsistency included important variations in point estimates, no overlapping of confidence intervals, inconsistency in direction of effect, and considerable between-study heterogeneity $\left(I^{2}>75 \%\right)$. Reasons of 
medRxiv preprint doi: https://doi.org/10.1101/2021.06.12.21258831; this version posted June 15, 2021. The copyright holder for this preprint (which was not certified by peer review) is the author/funder, who has granted medRxiv a license to display the preprint in perpetuity.

It is made available under a CC-BY-NC-ND 4.0 International license .

indirectness included differences in study populations and interventions, use of surrogate outcomes, and inadequate follow-up time. The width of $\mathrm{Cl}$ for the pooled estimates and the optimal information size (OIS) were analyzed for imprecision. ${ }^{20}$ OIS was calculated using the following formula ${ }^{21}$ : OIS $\left.=\left(4 \cdot\left(Z_{1-\alpha}+Z_{1-\beta}\right)^{2} \cdot P \cdot(1-P) / \delta^{2}\right) \cdot\left(1 / 1-I^{2}\right)\right)$, where $\alpha=5 \%, \beta=80 \%, P=$ control group risk, $\delta=$ difference between control group risk and intervention group risk, and $\mathrm{I}^{2}=$ between-study heterogeneity.

Although the funnel plot asymmetry was not evaluated, we reduced the potential for publication bias planning a comprehensive search including grey-literature without restrictions. In this criterion, we analyzed discrepancies in findings between peer-reviewed and non-peer reviewed publications and the influence of small trials ( $<100$ patients per arm) on estimated treatment effects. The influence of non-peer reviewed publications and small trials on the pooled estimates was analyzed using a "leave-one-out" sensitivity approach. ${ }^{22}$

\section{RESULTS}

Search strategy yielded 2871 potentially relevant records. After screening of titles and abstracts and evaluation of completed trials retrieved from ClinicalTrials.gov, 33 full-text articles were assessed for eligibility and 14 blinded, placebo-controlled RCTs ${ }^{23-36}$ were included in the metaanalysis. No trials evaluating the efficacy and safety of CQ in COVID-19 were found. Of the included trials, four ${ }^{33-36}$ used $\mathrm{HCQ}$ as a prophylactic medication pre-exposure to COVID-19, two $0^{31,32}$ as a prophylactic medication post-exposure to COVID-19, three ${ }^{28-30}$ as treatment for nonhospitalized patients, and five ${ }^{23-27}$ as treatment for hospitalized patients with COVID-19. A flow diagram of the study selection process and specific reasons for exclusion are detailed in Figure 1.

\subsection{HCQ as pre-exposure prophylaxis to prevent SARS-CoV-2 infection}

Population included healthcare workers in the USA, Canada, Mexico, and Pakistan at high-risk of exposure to SARS-CoV-2. Trials enrolled individuals with no history of SARS-CoV-2 infection and no symptoms suggestive of COVID-19. All trial protocols were registered on ClinicalTrials.gov, had a parallel design, and were classified as Phase 2 or Phase 3. Dosage regimens of HCQ were different between studies and outcomes were assessed up to 8 or 12 weeks (Table S1; supplementary file). Most studies had a low risk for selection, performance, detection, attrition, and information bias. One study was designed as a single blinded RCT and classified as having a 
medRxiv preprint doi: https://doi.org/10.1101/2021.06.12.21258831; this version posted June 15, 2021. The copyright holder for this preprint (which was not certified by peer review) is the author/funder, who has granted medRxiv a license to display the preprint in perpetuity.

It is made available under a CC-BY-NC-ND 4.0 International license .

high risk for detection bias. ${ }^{34}$ There was potential risk for reporting bias of some outcomes and a high risk for operational bias in all studies (Figure S1; supplementary file).

The four blinded, placebo-controlled RCTs enrolled a total of 1942 healthcare workers, 1271 in the HCQ group and 671 in the placebo group. Individual results showed no clinical benefit on HCQ use as pre-exposure prophylaxis to prevent SARS-CoV-2 infection (Table S2; supplementary file). In the meta-analysis, we found no decreased risk of SARS-CoV-2 infection (RR = 0.90; 95\% $\mathrm{Cl} 0.46$ to 1.77$)$ and no increased risk for any adverse events ( $R R=1.36 ; 95 \% \mathrm{Cl} 0.91$ to 2.03$)$ for healthcare workers receiving HCQ. The quality of evidence was graded as low for the outcomes of interest (Table 1) (Figures S2 and S3; supplementary file).

This meta-analysis included results of two peer-reviewed studies ${ }^{33,36}$ and two studies published in grey-literature. ${ }^{34,35}$ In the sensitivity analysis, peer-reviewed studies showed no decreased risk of SARS-CoV-2 infection ( $R R=0.76 ; 95 \% \mathrm{Cl} 0.52$ to 1.10 ) but an increased risk for any adverse events ( $R R=1.60 ; 95 \% \mathrm{Cl} 1.33$ to 1.92 ) among those using $\mathrm{HCQ}$, and the certainty was graded as moderate and high, respectively. No effect on the use of HCQ was found summarizing the results from non-peer reviewed publications and the quality of evidence was classified as very-low (Table S3; supplementary file).

\subsection{HCQ as post-exposure prophylaxis to prevent SARS-CoV-2 infection}

The studies were conducted in the USA and Canada and included adults who had close contact (occupational or household exposure) with a person with known SARS-CoV-2 infection within the prior 96 hours. During trial enrollment in both studies, eligible participants with symptoms consistent with COVID-19 were excluded. All trial protocols were registered on ClinicalTrials.gov, had a parallel design, and were classified as Phase $2 / 3$ or Phase 3. Dosage regimens of HCQ were different between studies and outcomes were assessed within 14 days (Table S4; supplementary file). Studies evaluating HCQ as post-exposure prophylaxis to prevent SARS-CoV-2 infection had a low risk for selection, performance, detection, attrition, reporting, and information bias. However, a high risk for operational bias was detected in both trials (Figure S4; supplementary file).

The two blinded, placebo-controlled RCTs enrolled a total of 1650 individuals, 821 in the HCQ group and 829 in the placebo group. Individual results showed no clinical benefit on HCQ use as post-exposure prophylaxis to prevent SARS-CoV-2 infection (Table S5; supplementary file). In the meta-analysis, we found no decreased risk of SARS-CoV-2 infection (RR $=0.96 ; 95 \% \mathrm{Cl} 0.72$ to 
medRxiv preprint doi: https://doi.org/10.1101/2021.06.12.21258831; this version posted June 15, 2021. The copyright holder for this preprint (which was not certified by peer review) is the author/funder, who has granted medRxiv a license to display the preprint in perpetuity.

It is made available under a CC-BY-NC-ND 4.0 International license .

1.29) among individuals receiving $H C Q$, but there was an increased risk for any adverse events within 14 days after trial enrollment ( $R R=1.91 ; 95 \% \mathrm{Cl} 1.20$ to 3.04). Included studies were peerreviewed and the quality of evidence was graded as moderate for the outcomes of interest (Table 2) (Figures S5 and S6; supplementary file).

\subsection{HCQ as treatment for non-hospitalized patients with COVID-19}

The studies were conducted in the USA, Canada and Brazil and included symptomatic, nonhospitalized adults with either laboratory-confirmed SARS-CoV-2 infection or COVID-19compatible symptoms. All trial protocols were registered on ClinicalTrials.gov, had a parallel design, and were classified as Phase $2 / 3$ or Phase 3. Dosage regimens of HCQ were different between studies and outcomes were assessed between 14 and 90 days (Table S6; supplementary file). All studies evaluating HCQ as treatment of non-hospitalized patients with COVID-19 had a low risk for selection, performance, attrition, and information bias. There was an unclear risk for detection bias in the study by Johnston et al. ${ }^{28}$ and a high risk for reporting bias in the study by Reis et al. ${ }^{29}$ due to the differences in the evaluation time of primary outcomes between trial protocol and full report. All trials were rated as a high risk of operational bias (Figure S7; supplementary file).

The three blinded, placebo-controlled RCTs enrolled a total of 1018 individuals, 497 in the HCQ group and 521 in the placebo group. Individual results showed no clinical benefit on HCQ use as treatment for non-hospitalized patients with COVID-19 (Table S7; supplementary file). In the meta-analysis, we found no decreased risk of hospitalization ( $R R=0.64 ; 95 \% \mathrm{Cl} 0.33$ to 1.23 ) and death $(R R=0.62 ; 95 \% \mathrm{Cl} 0.08$ to 4.68$)$ and no increased risk of any adverse events ( $R R=1.43$; $95 \% \mathrm{Cl} 0.85$ to 2.38 ) among outpatients with COVID-19 receiving $\mathrm{HCQ}$. Included studies were peer-reviewed and the quality of evidence was graded as moderate for hospitalization and death, and low for any adverse events (Table 3) (Figures S8 - S10; supplementary file).

\subsection{HCQ as treatment for hospitalized patients with COVID-19}

The studies were conducted in the USA, Mexico and France and included non-critically and critically ill patients with COVID-19 requiring hospitalization. All trial protocols were registered on ClinicalTrials.gov, had a parallel design, and were classified as Phase 2 or Phase 3. Dosage regimens of $\mathrm{HCQ}$ were similar in most studies and outcomes were assessed up to 14 and 28-30 days (Table S8; supplementary file). Most studies evaluating HCQ as treatment for hospitalized 
medRxiv preprint doi: https://doi.org/10.1101/2021.06.12.21258831; this version posted June 15, 2021. The copyright holder for this preprint (which was not certified by peer review) is the author/funder, who has granted medRxiv a license to display the preprint in perpetuity.

It is made available under a CC-BY-NC-ND 4.0 International license.

patients with COVID-19 had a low risk for selection, performance, detection, attrition, and information bias. There was potential risk for reporting bias of some outcomes in three studies. ${ }^{24-}$ ${ }^{26}$ All trials were rated as a high risk of operational bias (Figure S11; supplementary file).

The five blinded, placebo-controlled RCTs enrolled a total of 1138 individuals, 572 in the HCQ group and 566 in the placebo group. Individual results showed no clinical benefit on HCQ use as treatment for hospitalized patients with COVID-19 (Table S9; supplementary file). In the metaanalysis, we found no difference in the length of hospital stay between patients treated with HCQ and placebo ( $M D=1.20 ; 95 \% \mathrm{Cl}-0.32$ to 2.72 ) (Figure 2). There was no decreased risk of mechanical ventilation ([2 weeks] $\mathrm{RR}=0.81 ; 95 \% \mathrm{Cl} 0.49$ to 1.34 ; [4 weeks] $\mathrm{RR}=0.97 ; 95 \% \mathrm{Cl} 0.52$ to 1.80 ) and death ([2 weeks] $\mathrm{RR}=1.05 ; 95 \% \mathrm{Cl} 0.62$ to 1.78 ; [4 weeks] $\mathrm{RR}=0.87 ; 95 \% \mathrm{Cl} 0.67$ to 1.13) among hospitalized patients with COVID-19 receiving $\mathrm{HCQ}$. No increased risk of any adverse events was found ( $R R=1.07 ; 95 \% \mathrm{Cl} 0.89$ to 1.29) (Table 4) (Figures S12 - S16; supplementary file).

All trials evaluating the need for mechanical ventilation and any adverse events were peerreviewed as well as trials reporting data on deaths during two weeks of follow-up. Of the five trials reporting data on deaths during four weeks of follow-up, three were peer-reviewed $23,24,27$ and two were non-peer reviewed publications. ${ }^{25,26}$ The quality of evidence was graded as moderate for the outcomes of interest (Table 4). In the sensitivity analysis for mortality during four weeks of follow-up, we found no decreased risk for death from peer reviewed $(R R=0.88$; $95 \% \mathrm{Cl} 0.58$ to 1.33 ) and non-peer reviewed ( $R R=0.80 ; 95 \% \mathrm{Cl} 0.42$ to 1.55$)$ publications, and the quality of evidence was also classified as moderate (Table S10; supplementary file).

\subsection{Risk of any and serious adverse events, QTc interval $>500 \mathrm{~ms}$ and other cardiac manifestations,} gastrointestinal symptoms, headache, rash, and neurologic reactions for individuals using HCQ

We found an increased risk for any adverse events ( $R R=1.38 ; 95 \% \mathrm{Cl} 1.12$ to 1.71$)$ and gastrointestinal symptoms ( $\mathrm{RR}=2.45 ; 95 \% \mathrm{Cl} 1.77$ to 3.39 ) among individuals treated with $\mathrm{HCQ}$. However, there was no increased risk for serious adverse events ( $R R=1.07 ; 95 \% \mathrm{Cl} 0.69$ to 1.67 ), QTc $>500 \mathrm{~ms}$ ( $\mathrm{RR}=2.13 ; 95 \% \mathrm{Cl} 0.96$ to 4.71 ) and other cardiac manifestations ( $\mathrm{RR}=1.52 ; 95 \%$ 0.60 to 3.83 ), headache ( $R R=0.93 ; 95 \% \mathrm{Cl} 0.55$ to 1.56 ), skin rash ( $R R=1.46 ; 95 \% \mathrm{Cl} 0.89$ to 2.29 ), and neurologic reactions ( $R R=1.20 ; 95 \% \mathrm{Cl} 0.80$ to 1.78 ) (Table 5) (Figures S17 - S24; supplementary file). 
medRxiv preprint doi: https://doi.org/10.1101/2021.06.12.21258831; this version posted June 15, 2021. The copyright holder for this preprint (which was not certified by peer review) is the author/funder, who has granted medRxiv a license to display the preprint in perpetuity.

It is made available under a CC-BY-NC-ND 4.0 International license .

\section{DISCUSSION}

There is still no optimal approach toward COVID-19 management and several repurposing drugs including remdesivir, ivermectin, colchicine, favipiravir, lopinavir-ritonavir, ribavirin, interferon, $\mathrm{CQ}$ and HCQ have been tested for prevention and treatment of disease. Despite drug repurposing played a critical role in the identification of rapidly available therapeutic solutions against SARSCoV-2 infection ${ }^{37}$, to date only remdesivir and tocilizumab were approved by the US Food and Drug Administration (FDA) and other healthy agencies for the treatment of hospitalized patients with COVID-19. The evidence for repurposing HCQ is based on decreased viral replication in vitro but results from clinical data are contrasting. In this systematic review and meta-analysis, we synthesized the available evidence on the efficacy and safety of HCQ in prevention and treatment of COVID-19 based on the results of blinded, placebo-controlled RCTs. Our findings confirm the ineffectiveness of HCQ against COVID-19 in the current state of the art as established by best practices.

$\mathrm{HCQ}$, a 4-aminoquinoline compound used as an antimalarial drug, was reported to be effective in inhibiting SARS-CoV-2 infection in vitro due to the intracellular $\mathrm{pH}$ change and interference with the glycosylation of ACE2 receptor and the spike protein leading to block the virus entry into target cells. ${ }^{1}$ Despite promising preclinical results, $\mathrm{HCQ}$ has not been shown effective as pre- and post-exposure prophylaxis to COVID-19. The National Institutes of Health $(\mathrm{NIH})^{38}, \mathrm{WHO}^{11}$ and the European Medical Agency (EMA) ${ }^{39}$ have not recommend the use of any drug as prophylaxis against SARS-CoV-2 infection, except in clinical trials. The use of general prevention measures such as mask wearing, hand hygiene, and physical distancing remain indicated and are effective nonpharmacologic interventions to reduce the spread of this infection. ${ }^{40,41}$ In addition, it has been shown that vaccines currently available are 50\%-95\% effective in preventing COVID-19. ${ }^{42-47}$ Mass vaccination is the most cost-effective measure for controlling and preventing SARS-CoV-2 infection.

Currently, there is a consensus that symptomatic cases of COVID-19 require supportive care with medical evaluation, stratification of risk factors for worse clinical outcomes ${ }^{48-50}$, clinical monitoring of symptoms, and complementary exams if indicated. Measures to reduce the risk of SARS-CoV-2 transmission as patient isolation should also be guided. In outpatients, symptomatic treatment includes analgesics and antipyretics. For patients with dyspnea, prone positioning and respiratory physiotherapy may be indicated. ${ }^{51,52}$ Regular fluid intake should also be advised to avoid dehydration, and walking should be encouraged according to the patient's tolerance. SARSCoV-2 specific monoclonal antibodies (bamlanivimab, bamlanivimab with etesevimab, and 
medRxiv preprint doi: https://doi.org/10.1101/2021.06.12.21258831; this version posted June 15, 2021. The copyright holder for this preprint (which was not certified by peer review) is the author/funder, who has granted medRxiv a license to display the preprint in perpetuity.

It is made available under a CC-BY-NC-ND 4.0 International license .

casirivimab with imdevimab) have been considered in the treatment of outpatients with mild to moderate COVID-19, in the presence of high-risk criteria. ${ }^{53-58}$ In clinical trials, HCQ has not been associated with a reduction in the prevalence, severity, or duration of COVID-19 symptoms ${ }^{28-30}$, and there is no decreased risk of hospitalization for outpatients with SARS-CoV-2 infection treated with the drug. One of the hypotheses raised for the lack of response of HCQ in the clinical trials is that patients would have achieved minimal concentrations lower than the target concentration identified from in vitro assays. However, in at least one trial, HCQ dose was designed to achieve and maintain drug concentration above half the estimated maximum effective concentration (EC50) for SARS-CoV-2. ${ }^{30}$

Patients with persistent dyspnea, chest pain, hypoxia with a measured oxygen saturation below $94 \%$, altered mental status, or persistent fever should be evaluated for the need of hospital admission. In hospitalized patients, treatment includes supplemental oxygen and prone position when necessary, and adequate management of pulmonary ventilation..$^{59-62}$ Extracorporeal membrane oxygenation has been indicated in severe refractory cases. ${ }^{63-66}$ For some patients, SARS-CoV-2 infection may lead to a massive release of proinflammatory cytokines and hypercoagulable state increasing the risk for thromboembolic events. ${ }^{67-69}$ In clinical practice, the decision to prescribe low molecular weight heparin (LMWH) or unfractionated heparin has been made on a case-by-case basis. ${ }^{70}$ Despite real world evidence recommending the use of prophylactic anticoagulation for patients with COVID-19 on hospital admission ${ }^{71}$, recent openlabel RCTs ${ }^{72,73}$ showed that prophylactic or therapeutic anticoagulation did not result in clinical improvement for hospitalized patients with COVID-19, except in the context of diagnosing a thromboembolic event.

In hospitalized patients with COVID-19, dexamethasone was shown to reduce mortality in patients who required supplemental oxygen. ${ }^{74}$ Remdesivir, an FDA-approved intravenous antiviral drug, has been associated in double-blinded, placebo-controlled RCTs with a faster time to clinical improvement in severe cases of COVID-19, but results on mortality are contrasting. ${ }^{75,76}$ Recently, there is emerging evidence on the efficacy of tocilizumab, an interleukin-6 inhibitor, on clinical outcomes in critical COVID-19 patients with systemic inflammation and rapid respiratory deterioration. ${ }^{77,78}$ In hospital setting, our results found no difference in the length of stay and no decreased risk for mechanical ventilation and deaths among patients treated with $\mathrm{HCQ}$ compared to placebo.

In addition to not having found clinical benefits of HCQ to prevent or treat COVID-19, our results demonstrated an increased risk for any adverse events and gastrointestinal symptoms among 
medRxiv preprint doi: https://doi.org/10.1101/2021.06.12.21258831; this version posted June 15, 2021. The copyright holder for this preprint

(which was not certified by peer review) is the author/funder, who has granted medRxiv a license to display the preprint in perpetuity.

It is made available under a CC-BY-NC-ND 4.0 International license.

those using HCQ. Although a higher proportion of individuals treated with HCQ had QTc interval $>500 \mathrm{~ms}$ compared to placebo (5.0\% vs. $2.2 \%)$, there is no statistical difference between groups and no cases of arrhythmia or death associated to HCQ were reported. However, we must consider the fact that patients at higher risk of cardiotoxicity were excluded from these studies and the indiscriminate use of these drugs should be avoided.

Out results had limitations and included trials with a high risk for operational bias. In addition, we found an important influence of non-peer reviewed studies in the quality of evidence for some outcomes of interest. However, the certainty of the results on the lack of clinical benefit for HCQ was rated as moderate and we believe that the true effect is probably close to the estimated effect. Finally, we lack in analyzing potential adverse events dose-response relationships in patients treated with $\mathrm{HCQ}$.

\section{CONCLUSION}

Available evidence based on the results of blinded, placebo-controlled RCTs showed no clinical benefits of HCQ as pre-and post-exposure prophylaxis and treatment of non-hospitalized and hospitalized patients with COVID-19.

\section{CONFLICT OF INTEREST}

The authors declare no conflict of interest.

\section{ACKNOWLEDGMENTS}

To all health professionals who are facing the COVID-19 pandemic.

\section{DATA AVAILABILITY STATEMENT}

The data sets used and/or analyzed during the current study are available from the corresponding author on reasonable request. 
medRxiv preprint doi: https://doi.org/10.1101/2021.06.12.21258831; this version posted June 15, 2021. The copyright holder for this preprint (which was not certified by peer review) is the author/funder, who has granted medRxiv a license to display the preprint in perpetuity.

It is made available under a CC-BY-NC-ND 4.0 International license .

\section{REFERENCES}

1. Liu J, Cao R, Xu M, et al. Hydroxychloroquine, a less toxic derivative of chloroquine, is effective in inhibiting SARS-CoV-2 infection in vitro. Cell Discovery. 2020;6(1). doi:10.1038/s41421-020-0156-0

2. Wang $M$, Cao $R$, Zhang $L$, et al. Remdesivir and chloroquine effectively inhibit the recently emerged novel coronavirus (2019-nCoV) in vitro. Cell Research. 2020;30(3):269-271. doi:10.1038/s41422-020-0282-0

3. Heimfarth L, Serafini MR, Martins-Filho PR, Quintans J de SS, Quintans-Júnior L. Drug repurposing and cytokine management in response to COVID-19: A review. International Immunopharmacology. 2020;88. doi:10.1016/j.intimp.2020.106947

4. Gautret $P$, Lagier J-C, Parola $P$, et al. Hydroxychloroquine and azithromycin as a treatment of COVID-19: results of an open-label non-randomized clinical trial. International Journal of Antimicrobial Agents. 2020;56(1):undefined. doi:10.1016/j.ijantimicag.2020.105949

5. Chen X, Geiger JD. Janus sword actions of chloroquine and hydroxychloroquine against COVID-19. Cellular Signalling. 2020;73. doi:10.1016/j.cellsig.2020.109706

6. Axfors $C$, Schmitt AM, Janiaud $P$, et al. Mortality outcomes with hydroxychloroquine and chloroquine in COVID-19 from an international collaborative meta-analysis of randomized trials. Nature Communications. 2021;12(1). doi:10.1038/s41467-02122446-z

7. Bartoszko JJ, Siemieniuk RAC, Kum E, et al. Prophylaxis against covid-19: living systematic review and network meta-analysis. BMJ. Published online April 26, 2021. doi:10.1136/bmj.n949

8. Eze P, Mezue KN, Nduka CU, Obianyo I, Egbuche O. Efficacy and safety of chloroquine and hydroxychloroquine for treatment of COVID-19 patients-a systematic review and meta-analysis of randomized controlled trials. American Journal of Cardiovascular Disease. 2021;11(1):93-107.

9. Million $\mathrm{M}$, Gautret $\mathrm{P}$, Colson $\mathrm{P}$, et al. Clinical efficacy of chloroquine derivatives in COVID-19 infection: comparative meta-analysis between the big data and the real world. New Microbes and New Infections. 2020;38. doi:10.1016/j.nmni.2020.100709

10. di Castelnuovo A, Costanzo S, Cassone antonio, Cauda R, Gaetano G de, lacoviello L. Low dose hydroxychloroquine is associated with lower mortality in COVID-19: a metaanalysis of 26 studies and 44,521 patients. medRxiv. Published online November 4, 2020:1-31.

11. World Health Organization. Coronavirus disease (COVID-19): Hydroxychloroquine. https://www.who.int/news-room/q-a-detail/coronavirus-disease-(covid-19)hydroxychloroquine.

12. Saag MS. Misguided Use of Hydroxychloroquine for COVID-19. JAMA. 2020;324(21):2161-2162. doi:10.1001/jama.2020.22389 
medRxiv preprint doi: https://doi.org/10.1101/2021.06.12.21258831; this version posted June 15, 2021. The copyright holder for this preprint (which was not certified by peer review) is the author/funder, who has granted medRxiv a license to display the preprint in perpetuity.

It is made available under a CC-BY-NC-ND 4.0 International license .

13. Higgins JPT, Altman DG, Gotzsche PC, et al. The Cochrane Collaboration's tool for assessing risk of bias in randomised trials. BMJ. 2011;343. doi:10.1136/bmj.d5928

14. Hozo SP, Djulbegovic B, Hozo I. Estimating the mean and variance from the median, range, and the size of a sample. BMC Medical Research Methodology. 2005;5(1). doi:10.1186/1471-2288-5-13

15. Higgins JPT, Thompson SG. Quantifying heterogeneity in a meta-analysis. Statistics in Medicine. 2002;21(11). doi:10.1002/sim.1186

16. Simmonds M. Quantifying the risk of error when interpreting funnel plots. Systematic Reviews. 2015;4(1). doi:10.1186/s13643-015-0004-8

17. Guyatt GH, Oxman AD, Kunz R, Vist GE, Falck-Ytter Y, Schünemann HJ. What is "quality of evidence" and why is it important to clinicians? BMJ. 2008;336(7651).

doi:10.1136/bmj.39490.551019.BE

18. Guyatt $\mathrm{GH}, \mathrm{Oxman} A \mathrm{D}$, Vist $\mathrm{GE}$, et al. GRADE: an emerging consensus on rating quality of evidence and strength of recommendations. BMJ. 2008;336(7650).

doi:10.1136/bmj.39489.470347.AD

19. Meader N, King K, Llewellyn A, et al. A checklist designed to aid consistency and reproducibility of GRADE assessments: development and pilot validation. Systematic Reviews. 2014;3(1). doi:10.1186/2046-4053-3-82

20. Guyatt GH, Oxman AD, Kunz R, et al. GRADE guidelines 6 . Rating the quality of evidence-imprecision. Journal of Clinical Epidemiology. 2011;64(12).

doi:10.1016/j.jclinepi.2011.01.012

21. Thorlund K, Imberger G, Walsh M, et al. The Number of Patients and Events Required to Limit the Risk of Overestimation of Intervention Effects in Meta-Analysis-A Simulation Study. PLOS ONE. 2011;6(10). doi:10.1371/journal.pone.0025491

22. Sterne JAC, Egger M, Smith GD. Systematic reviews in health care: Investigating and dealing with publication and other biases in meta-analysis. BMJ. 2001;323(7304). doi:10.1136/bmj.323.7304.101

23. Self WH, Semler MW, Leither LM, et al. Effect of Hydroxychloroquine on Clinical Status at 14 Days in Hospitalized Patients With COVID-19. JAMA. 2020;324(21):2165-2176. doi:10.1001/jama.2020.22240

24. Ulrich RJ, Troxel AB, Carmody E, et al. Treating COVID-19 With Hydroxychloroquine (TEACH): A Multicenter, Double-Blind Randomized Controlled Trial in Hospitalized Patients. Open Forum Infectious Diseases. 2020;7(10). doi:10.1093/ofid/ofaa446

25. Gonzalez JLB, González Gámez M, Enciso EAM, et al. Efficacy and safety of Ivermectin and Hydroxychloroquine in patients with severe COVID-19. A randomized controlled trial. medRxiv. Published online February 23, 2021.

26. Hernandez-Cardenas C, Thirion-Romero I, Rivera-Martinez NE, Meza-Meneses P, Remigio-Luna A, Perez-Padilla R. Hydroxychloroquine for the treatment of severe respiratory infection by covid-19: a randomized controlled trial. medRxiv. Published online February 5, 2021. 
medRxiv preprint doi: https://doi.org/10.1101/2021.06.12.21258831; this version posted June 15, 2021. The copyright holder for this preprint (which was not certified by peer review) is the author/funder, who has granted medRxiv a license to display the preprint in perpetuity.

It is made available under a CC-BY-NC-ND 4.0 International license .

27. Dubée V, Roy P-M, Vielle B, et al. Hydroxychloroquine in mild-to-moderate coronavirus disease 2019: a placebo-controlled double blind trial. Clinical Microbiology and Infection. Published online April 2021. doi:10.1016/j.cmi.2021.03.005

28. Johnston C, Brown ER, Stewart J, et al. Hydroxychloroquine with or without azithromycin for treatment of early SARS-CoV-2 infection among high-risk outpatient adults: A randomized clinical trial. EClinicalMedicine. 2021;33.

doi:10.1016/j.eclinm.2021.100773

29. Reis G, Moreira Silva EA dos S, Medeiros Silva DC, et al. Effect of Early Treatment With Hydroxychloroquine or Lopinavir and Ritonavir on Risk of Hospitalization Among Patients With COVID-19. JAMA Network Open. 2021;4(4). doi:10.1001/jamanetworkopen.2021.6468

30. Skipper CP, Pastick KA, Engen NW, et al. Hydroxychloroquine in Nonhospitalized Adults With Early COVID-19. Annals of Internal Medicine. 2020;173(8):434-435. doi:10.7326/M20-4207

31. Boulware DR, Pullen MF, Bangdiwala AS, et al. A Randomized Trial of Hydroxychloroquine as Postexposure Prophylaxis for Covid-19. New England Journal of Medicine. 2020;383(6):517-525. doi:10.1056/NEJMoa2016638

32. Barnabas R v., Brown ER, Bershteyn A, et al. Hydroxychloroquine as Postexposure Prophylaxis to Prevent Severe Acute Respiratory Syndrome Coronavirus 2 Infection. Annals of Internal Medicine. 2021;174(3):344-352. doi:10.7326/M20-6519

33. Rajasingham R, Bangdiwala AS, Nicol MR, et al. Hydroxychloroquine as Pre-exposure Prophylaxis for Coronavirus Disease 2019 (COVID-19) in Healthcare Workers: A Randomized Trial. Clinical Infectious Diseases. 2021;72(11):e835-e843. doi:10.1093/cid/ciaa1571

34. Syed F, Arif MA, Niazi R, et al. Pre-Exposure Prophylaxis with Various Doses of Hdroxychloroquine among high-risk COVID 19 Healthcare Personnel: CHEER randomized controlled trial. medRxiv. Published online May 17, 2021.

35. Rojas-Serrano J, Thirion-Romero AMP-VI, Vázquez-Pérez J, Ramírez-Venegas FM-NA, Pérez-Kawabe KM, Pérez-Padilla R. Hydroxychloroquine For Prophylaxis Of COVID-19 In Health Workers: A Randomized Clinical Trial. medRxiv. Published online May 16, 2021.

36. Abella BS, Jolkovsky EL, Biney BT, et al. Efficacy and Safety of Hydroxychloroquine vs Placebo for Pre-exposure SARS-CoV-2 Prophylaxis Among Health Care Workers. JAMA Internal Medicine. 2021;181(2):195-202. doi:10.1001/jamainternmed.2020.6319

37. Martinez MA. Lack of Effectiveness of Repurposed Drugs for COVID-19 Treatment. Frontiers in Immunology. 2021;12. doi:10.3389/fimmu.2021.635371

38. National Institutes of Health. Prevention and Prophylaxis of SARS-CoV-2 Infection. Prevention and Prophylaxis of SARS-CoV-2 Infection. Published April 21, 2021. Accessed June 11, 2021. https://www.covid19treatmentguidelines.nih.gov/overview/preventionof-sars-cov-2/

39. European Medicines Agency. COVID-19: chloroquine and hydroxychloroquine only to be used in clinical trials or emergency use programmes. 
medRxiv preprint doi: https://doi.org/10.1101/2021.06.12.21258831; this version posted June 15, 2021. The copyright holder for this preprint (which was not certified by peer review) is the author/funder, who has granted medRxiv a license to display the preprint in perpetuity.

It is made available under a CC-BY-NC-ND 4.0 International license .

https://www.ema.europa.eu/en/news/covid-19-chloroquine-hydroxychloroquine-onlybe-used-clinical-trials-emergency-use-programmes.

40. Chu DK, Akl EA, Duda S, et al. Physical distancing, face masks, and eye protection to prevent person-to-person transmission of SARS-CoV-2 and COVID-19: a systematic review and meta-analysis. The Lancet. 2020;395(10242):1973-1987. doi:10.1016/S01406736(20)31142-9

41. Brooks JT, Butler JC. Effectiveness of Mask Wearing to Control Community Spread of SARS-CoV-2. JAMA. 2021;325(10):998-999. doi:10.1001/jama.2021.1505

42. Palacios R, Batista AP, Albuquerque CSN, et al. Efficacy and Safety of a COVID-19 Inactivated Vaccine in Healthcare Professionals in Brazil: The PROFISCOV Study. SSRN Electronic Journal. Published online 2021. doi:10.2139/ssrn.3822780

43. Wu Z, Hu Y, Xu M, et al. Safety, tolerability, and immunogenicity of an inactivated SARSCoV-2 vaccine (CoronaVac) in healthy adults aged 60 years and older: a randomised, double-blind, placebo-controlled, phase $1 / 2$ clinical trial. The Lancet Infectious Diseases. 2021;21(6):803-812. doi:10.1016/S1473-3099(20)30987-7

44. Voysey M, Clemens SAC, Madhi SA, et al. Safety and efficacy of the ChAdOx1 nCoV-19 vaccine (AZD1222) against SARS-CoV-2: an interim analysis of four randomised controlled trials in Brazil, South Africa, and the UK. The Lancet. 2021;397(10269):99111. doi:10.1016/S0140-6736(20)32661-1

45. Baden LR, el Sahly HM, Essink B, et al. Efficacy and Safety of the mRNA-1273 SARS-CoV2 Vaccine. New England Journal of Medicine. 2021;384(5):403-416. doi:10.1056/NEJMoa2035389

46. Polack FP, Thomas SJ, Kitchin N, et al. Safety and Efficacy of the BNT162b2 mRNA Covid19 Vaccine. New England Journal of Medicine. 2020;383(27):2603-2615. doi:10.1056/NEJMoa2034577

47. Sadoff J, Gray G, Vandebosch A, et al. Safety and Efficacy of Single-Dose Ad26.COV2.S Vaccine against Covid-19. New England Journal of Medicine. 2021;384(23):2187-2201. doi:10.1056/NEJMoa2101544

48. Li J, Huang DQ, Zou B, et al. Epidemiology of COVID-19: A systematic review and metaanalysis of clinical characteristics, risk factors, and outcomes. Journal of Medical Virology. 2021;93(3):1449-1458. doi:10.1002/jmv.26424

49. Martins-Filho PR, Tavares CSS, Santos VS. Factors associated with mortality in patients with COVID-19. A quantitative evidence synthesis of clinical and laboratory data. European Journal of Internal Medicine. 2020;76:97-99. doi:10.1016/j.ejim.2020.04.043

50. Martins-Filho PR, Antunes de Souza Araújo A, Pereira LX, et al. Factors Associated with Mortality among Hospitalized Patients with COVID-19: A Retrospective Cohort Study. The American Journal of Tropical Medicine and Hygiene. 2021;104(1):103-105. doi:10.4269/ajtmh.20-1170

51. Jagan N, Morrow LE, Walters RW, et al. The POSITIONED Study: Prone Positioning in Nonventilated Coronavirus Disease 2019 Patients-A Retrospective Analysis. Critical Care Explorations. 2020;2(10). doi:10.1097/CCE.0000000000000229 
medRxiv preprint doi: https://doi.org/10.1101/2021.06.12.21258831; this version posted June 15, 2021. The copyright holder for this preprint (which was not certified by peer review) is the author/funder, who has granted medRxiv a license to display the preprint in perpetuity.

It is made available under a CC-BY-NC-ND 4.0 International license .

52. Touchon F, Trigui Y, Prud'homme E, et al. Awake prone positioning for hypoxaemic respiratory failure: past, COVID-19 and perspectives. European Respiratory Review. 2021;30(160). doi:10.1183/16000617.0022-2021

53. US Food and Drug Administration. Fact sheet for health care providers emergency use authorization (EUA) of bamlanivimab and etesevimab.

https://www.fda.gov/media/145802/download .

54. US Food and Drug Administration. Fact sheet for health care providers emergency use authorization (EUA) of bamlanivimab. https://www.fda.gov/media/143603/download .

55. Regeneron Pharmaceuticals Inc. Fact sheet for health care providers: emergency use authorization (EUA) of casirivimab and imdevimab. Regeneron.

https://www.regeneron.com/sites/default/files/treatment-covid19-eua-fact-sheet-forhcp.pdf .

56. Gottlieb RL, Nirula A, Chen P, et al. Effect of Bamlanivimab as Monotherapy or in Combination With Etesevimab on Viral Load in Patients With Mild to Moderate COVID19. JAMA. 2021;325(7):632-644. doi:10.1001/jama.2021.0202

57. Chen P, Nirula A, Heller B, et al. SARS-CoV-2 Neutralizing Antibody LY-CoV555 in Outpatients with Covid-19. New England Journal of Medicine. 2021;384(3):229-237. doi:10.1056/NEJMoa2029849

58. Taylor PC, Adams AC, Hufford MM, de la Torre I, Winthrop K, Gottlieb RL. Neutralizing monoclonal antibodies for treatment of COVID-19. Nature Reviews Immunology. 2021;21(6):382-393. doi:10.1038/s41577-021-00542-x

59. Avdeev SN, Yaroshetskiy Al, Tsareva NA, et al. Noninvasive ventilation for acute hypoxemic respiratory failure in patients with COVID-19. The American Journal of Emergency Medicine. 2021;39:154-157. doi:10.1016/j.ajem.2020.09.075

60. Grieco DL, Menga LS, Cesarano M, et al. Effect of Helmet Noninvasive Ventilation vs High-Flow Nasal Oxygen on Days Free of Respiratory Support in Patients With COVID-19 and Moderate to Severe Hypoxemic Respiratory Failure. JAMA. 2021;325(17):17311743. doi:10.1001/jama.2021.4682

61. Botta $\mathrm{M}$, Tsonas AM, Pillay J, et al. Ventilation management and clinical outcomes in invasively ventilated patients with COVID-19 (PRoVENT-COVID): a national, multicentre, observational cohort study. The Lancet Respiratory Medicine. 2021;9(2):139-148. doi:10.1016/S2213-2600(20)30459-8

62. Damanti S, Ramirez GA, Bozzolo EP, et al. 6-Month Respiratory Outcomes and Exercise Capacity of COVID-19 Acute Respiratory Failure Patients Treated With CPAP. Internal Medicine Journal. Published online May 7, 2021. doi:10.1111/imj.15345

63. Badulak J, Antonini MV, Stead CM, et al. Extracorporeal Membrane Oxygenation for COVID-19: Updated 2021 Guidelines from the Extracorporeal Life Support Organization. ASAIO Journal. 2021;67(5):485-495. doi:10.1097/MAT.0000000000001422

64. Lebreton $\mathrm{G}$, Schmidt $\mathrm{M}$, Ponnaiah $\mathrm{M}$, et al. Extracorporeal membrane oxygenation network organisation and clinical outcomes during the COVID-19 pandemic in Greater 
medRxiv preprint doi: https://doi.org/10.1101/2021.06.12.21258831; this version posted June 15, 2021. The copyright holder for this preprint (which was not certified by peer review) is the author/funder, who has granted medRxiv a license to display the preprint in perpetuity.

It is made available under a CC-BY-NC-ND 4.0 International license .

Paris, France: a multicentre cohort study. The Lancet Respiratory Medicine. Published online April 2021. doi:10.1016/S2213-2600(21)00096-5

65. Saeed O, Tatooles AJ, Farooq M, et al. Characteristics and outcomes of patients with COVID-19 supported by extracorporeal membrane oxygenation: A retrospective multicenter study. The Journal of Thoracic and Cardiovascular Surgery. Published online May 2021. doi:10.1016/j.jtcvs.2021.04.089

66. Lorusso R, Combes A, Coco V lo, et al. ECMO for COVID-19 patients in Europe and Israel. Intensive Care Medicine. 2021;47(3):344-348. doi:10.1007/s00134-020-06272-3

67. Lodigiani C, lapichino G, Carenzo L, et al. Venous and arterial thromboembolic complications in COVID-19 patients admitted to an academic hospital in Milan, Italy. Thrombosis Research. 2020;191:9-14. doi:10.1016/j.thromres.2020.04.024

68. Helms J, Tacquard C, Severac F, et al. High risk of thrombosis in patients with severe SARS-CoV-2 infection: a multicenter prospective cohort study. Intensive Care Medicine. 2020;46(6):1089-1098. doi:10.1007/s00134-020-06062-x

69. Abou-Ismail MY, Diamond A, Kapoor S, Arafah Y, Nayak L. The hypercoagulable state in COVID-19: Incidence, pathophysiology, and management. Thrombosis Research. 2020;194:101-115. doi:10.1016/j.thromres.2020.06.029

70. Soeiro A de M, Leal T de CAT, Pereira M de P, et al. Position Statement on the Use of Antiplatelet Agents and Anticoagulants in Patients Infected with the New Coronavirus (COVID-19) - 2020. Arquivos Brasileiros de Cardiologia. 2020;115(2):292-301. doi:10.36660/abc.20200424

71. Rentsch CT, Beckman JA, Tomlinson L, et al. Early initiation of prophylactic anticoagulation for prevention of coronavirus disease 2019 mortality in patients admitted to hospital in the United States: cohort study. BMJ. Published online February 11, 2021. doi:10.1136/bmj.n311

72. INSPIRATION Investigators. Effect of Intermediate-Dose vs Standard-Dose Prophylactic Anticoagulation on Thrombotic Events, Extracorporeal Membrane Oxygenation Treatment, or Mortality Among Patients With COVID-19 Admitted to the Intensive Care Unit. JAMA. 2021;325(16):1620-1630. doi:10.1001/jama.2021.4152

73. Lopes RD, de Barros e Silva PGM, Furtado RHM, et al. Therapeutic versus prophylactic anticoagulation for patients admitted to hospital with COVID-19 and elevated D-dimer concentration (ACTION): an open-label, multicentre, randomised, controlled trial. The Lancet. 2021;397(10291):2253-2263. doi:10.1016/S0140-6736(21)01203-4

74. RECOVERY Collaborative Group. Dexamethasone in Hospitalized Patients with Covid-19. New England Journal of Medicine. 2021;384(8):693-704. doi:10.1056/NEJMoa2021436

75. Wang Y, Zhang D, Du G, et al. Remdesivir in adults with severe COVID-19: a randomised, double-blind, placebo-controlled, multicentre trial. The Lancet. 2020;395(10236):15691578. doi:10.1016/S0140-6736(20)31022-9

76. Beigel JH, Tomashek KM, Dodd LE, et al. Remdesivir for the Treatment of Covid-19 Final Report. New England Journal of Medicine. 2020;383(19):1813-1826.

doi:10.1056/NEJMoa2007764 
medRxiv preprint doi: https://doi.org/10.1101/2021.06.12.21258831; this version posted June 15, 2021. The copyright holder for this preprint (which was not certified by peer review) is the author/funder, who has granted medRxiv a license to display the preprint in perpetuity.

It is made available under a CC-BY-NC-ND 4.0 International license.

77. RECOVERY Collaborative Group. Tocilizumab in patients admitted to hospital with COVID-19 (RECOVERY): a randomised, controlled, open-label, platform trial. Lancet. 2021;397(10285):1637-1645.

78. The REMAP-CAP Investigators. Interleukin-6 Receptor Antagonists in Critically III Patients with Covid-19. New England Journal of Medicine. 2021;384(16):1491-1502. doi:10.1056/NEJMoa2100433 
medRxiv preprint doi: https://doi.org/10.1101/2021.06.12.21258831; this version posted June 15, 2021. The copyright holder for this preprint

(which was not certified by peer review) is the author/funder, who has granted medRxiv a license to display the preprint in perpetuity.

It is made available under a CC-BY-NC-ND 4.0 International license.

\section{Identification of studies via databases and registers}

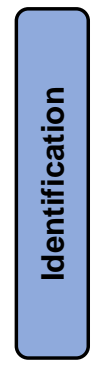

Records identified from:

Databases ( $n=1978$ ) (PubMed 121, Embase 986, Web of Science 866, Lilacs 5)

Trial registers or other grey literature sources $(n=893)$ (MedRxiv 885, ClinicalTrials.gov 8)
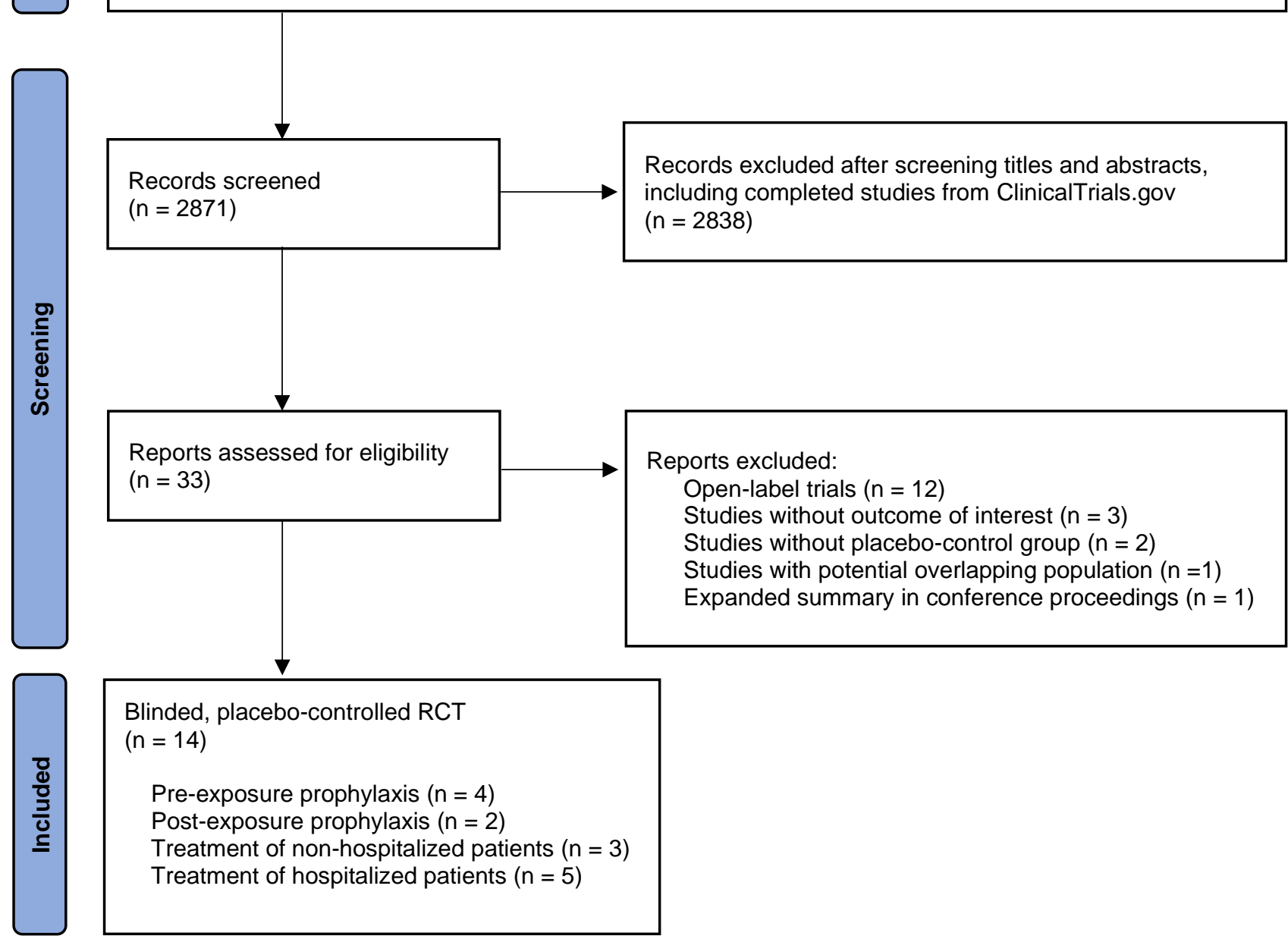

Blinded, placebo-controlled RCT

$(n=14)$

Pre-exposure prophylaxis $(n=4)$

Post-exposure prophylaxis $(n=2)$

Treatment of non-hospitalized patients $(n=3)$

Treatment of hospitalized patients $(n=5)$

Figure 1. PRISMA flow chart of studies screened and included.

Reports excluded:

Open-label trials $(n=12)$

Studies without outcome of interest $(n=3)$

Studies without placebo-control group $(n=2)$

Studies with potential overlapping population $(n=1)$

Expanded summary in conference proceedings $(n=1)$ 
medRxiv preprint doi: https://doi.org/10.1101/2021.06.12.21258831; this version posted June 15, 2021. The copyright holder for this preprint (which was not certified by peer review) is the author/funder, who has granted medRxiv a license to display the preprint in perpetuity.

$$
\text { It is made available under a CC-BY-NC-ND } 4.0 \text { International license. }
$$

\section{Study or Subgroup}

$$
\mathrm{HCQ} \quad \text { Placebo }
$$

Mean Difference

Mean Difference

Gonzalez 2021
Hernandez-Cardenas 2021
Ulrich 2020

Mean SD

Total Mean SD

Total Weight IV, Random, $95 \% \mathrm{Cl}$

\begin{tabular}{|c|c|c|c|c|c|c|c|}
\hline 6.3 & 4.4 & 33 & 5.3 & 2.2 & 37 & $55.0 \%$ & $1.00[-0.66,2.66]$ \\
\hline 17.8 & 11 & 106 & 18.1 & 12 & 108 & $21.1 \%$ & $-0.30[-3.38,2.78]$ \\
\hline 9.8 & 10.3 & 67 & 6.8 & 5.9 & 61 & $23.8 \%$ & $3.00[0.12,5.88]$ \\
\hline & & 206 & & & 206 & $100.0 \%$ & $1.20[-0.32,2.72]$ \\
\hline
\end{tabular}

IV, Random, $95 \% \mathrm{Cl}$

Heterogeneity: Tau $^{2}=0.38 ; \mathrm{Chi}^{2}=2.47, \mathrm{df}=2(\mathrm{P}=0.29) ; \mathrm{I}^{2}=19 \%$

Test for overall effect: $Z=1.55(P=0.12)$

Figure 2. Forest plot showing differences in length of hospital stay between patients treated with HCQ and placebo. 
Table 1. Evidence synthesis on the efficacy and safety of hydroxychloroquine as prophylactic medication pre-exposure to COVID-19.

\begin{tabular}{|c|c|c|c|c|c|c|}
\hline \multirow{2}{*}{ Outcomes } & \multicolumn{2}{|c|}{ Number of patients } & \multirow{2}{*}{$\mathrm{RR}(95 \% \mathrm{Cl})$} & \multirow{2}{*}{$p$-value } & \multirow{2}{*}{$1^{2}$} & \multirow{2}{*}{ Quality of evidence } \\
\hline & $\mathrm{HCQ}$ & Placebo & & & & \\
\hline Cases of SARS-CoV-2 infection & $105 / 1269(8.3 \%)$ & $56 / 666(8.4 \%)$ & 0.90 (0.46 to 1.77$)$ & 0.77 & $55 \%$ & $\oplus \oplus \bigcirc \bigcirc^{*}$ \\
\hline Any adverse events & $386 / 1217(31.7 \%)$ & $156 / 645(24.2 \%)$ & 1.36 (0.91 to 2.03$)$ & 0.14 & $73 \%$ & $\oplus \oplus \bigcirc \bigcirc^{* *}$ \\
\hline
\end{tabular}

$\mathrm{HCQ}$, hydroxychloroquine. RR, relative risk. $\mathrm{Cl}$, confidence interval.

Certainty: $\oplus$ very-low; $\oplus \oplus$ low; $\oplus \oplus \oplus$ moderate; $\oplus \oplus \oplus \oplus$ high.

* Risk of bias: not serious; Inconsistency: serious; Indirectness: not serious; Imprecision: serious; Discrepancies in findings between peer-reviewed and non-peer reviewed publications: no; Influence of small trials (<100 patients per arm): no; Large effect: no.

** Risk of bias: not serious; Inconsistency: serious; Indirectness: not serious; Imprecision: not serious; Discrepancies in findings between peer-reviewed and non-peer reviewed publications: yes; Influence of small trials (<100 patients per arm): strongly suspect; Large effect: no. 
Table 2. Evidence synthesis on the efficacy and safety of hydroxychloroquine as prophylactic medication post-exposure to COVID-19.

\begin{tabular}{|c|c|c|c|c|c|c|}
\hline \multirow{2}{*}{ Outcomes } & \multicolumn{2}{|c|}{ Number of patients } & \multirow{2}{*}{$\mathrm{RR}(95 \% \mathrm{Cl})$} & \multirow{2}{*}{$p$-value } & \multirow{2}{*}{$\mathrm{I}^{2}$} & \multirow{2}{*}{ Quality of evidence } \\
\hline & $\mathrm{HCQ}$ & Placebo & & & & \\
\hline Cases of SARS-CoV-2 infection & $102 / 767(13.3 \%)$ & $103 / 743(13.9 \%)$ & 0.96 (0.72 to 1.29$)$ & 0.79 & $24 \%$ & $\oplus \oplus \oplus \bigcirc^{*}$ \\
\hline Any adverse events & $206 / 756(27.3 \%)$ & 105/773 (13.6\%) & 1.91 (1.20 to 3.04$)$ & $<0.01$ & $77 \%$ & $\oplus \oplus \oplus \bigcirc^{* *}$ \\
\hline
\end{tabular}

$\mathrm{HCQ}$, hydroxychloroquine. RR, relative risk. $\mathrm{Cl}$, confidence interval.

Certainty: $\oplus$ very-low; $\oplus \oplus$ low; $\oplus \oplus \oplus$ moderate; $\oplus \oplus \oplus \oplus$ high.

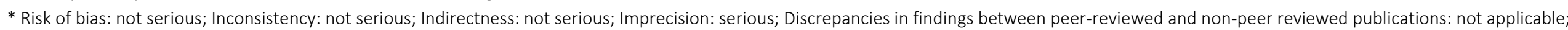
Influence of small trials (<100 patients per arm): not applicable; Large effect: no.

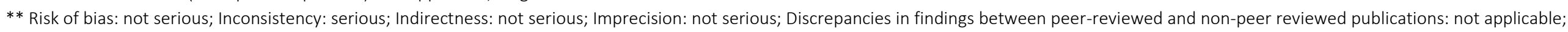
Influence of small trials (<100 patients per arm): not applicable; Large effect: no. 
Table 3. Evidence synthesis on the efficacy and safety of hydroxychloroquine as treatment for non-hospitalized patients with COVID-19.

\begin{tabular}{|c|c|c|c|c|c|c|}
\hline \multirow{2}{*}{ Outcomes } & \multicolumn{2}{|c|}{ Number of patients } & \multirow{2}{*}{$\mathrm{RR}(95 \% \mathrm{Cl})$} & \multirow{2}{*}{$\mathrm{p}$-value } & \multirow{2}{*}{$I^{2}$} & \multirow{2}{*}{ Quality of evidence } \\
\hline & $\mathrm{HCQ}$ & Placebo & & & & \\
\hline Hospitalizations & $14 / 497(2.8 \%)$ & $23 / 521$ (4.4\%) & 0.64 (0.33 to 1.23$)$ & 0.18 & $0 \%$ & $\oplus \oplus \oplus \bigcirc^{*}$ \\
\hline Deaths & $1 / 497(0.2 \%)$ & $2 / 521(0.4 \%)$ & 0.62 (0.08 to 4.68$)$ & 0.64 & $0 \%$ & $\oplus \oplus \oplus \bigcirc^{*}$ \\
\hline Any adverse events & $143 / 490(29.2 \%)$ & 97/514 (18.9\%) & 1.43 (0.85 to 2.38 ) & 0.18 & $72 \%$ & $\oplus \oplus \bigcirc \bigcirc^{* *}$ \\
\hline
\end{tabular}

$\mathrm{HCQ}$, hydroxychloroquine. $\mathrm{RR}$, relative risk. $\mathrm{Cl}$, confidence interval.

Certainty: $\oplus$ very-low; $\oplus \oplus$ low; $\oplus \oplus \oplus$ moderate; $\oplus \oplus \oplus \oplus$ high.

* / ** Risk of bias: not serious; Inconsistency: not serious; Indirectness: not serious; Imprecision: serious; Discrepancies in findings between peer-reviewed and non-peer reviewed publications:

not applicable; Influence of small trials (<100 patients per arm): no; Large effect: no.

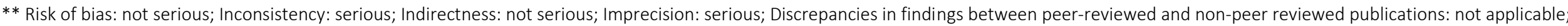

Influence of small trials (<100 patients per arm): no; Large effect: no. 
Table 4. Evidence synthesis on the efficacy and safety of hydroxychloroquine as treatment for hospitalized patients with COVID-19.

\begin{tabular}{|c|c|c|c|c|c|c|}
\hline \multirow{2}{*}{ Outcomes } & \multicolumn{2}{|c|}{ Number of patients } & \multirow{2}{*}{$\mathrm{RR}(95 \% \mathrm{Cl})$} & \multirow{2}{*}{$p$-value } & \multirow{2}{*}{$I^{2}$} & \multirow{2}{*}{ Quality of evidence } \\
\hline & $\mathrm{HCQ}$ & Placebo & & & & \\
\hline \multicolumn{7}{|c|}{ Mechanical ventilation } \\
\hline 2 weeks & 26/433 (6.0\%) & $31 / 421(7.4 \%)$ & 0.81 (0.49 to 1.34$)$ & 0.42 & $0 \%$ & $\oplus \oplus \oplus \bigcirc^{*}$ \\
\hline 4 weeks & $19 / 433(4.4 \%)$ & $19 / 421(4.5 \%)$ & 0.97 (0.52 to 1.80$)$ & 0.91 & $0 \%$ & $\oplus \oplus \oplus \bigcirc^{*}$ \\
\hline \multicolumn{7}{|l|}{ Death } \\
\hline 2 weeks & $27 / 433(6.2 \%)$ & 25/421 (5.9\%) & 1.05 (0.62 to 1.78$)$ & 0.86 & $0 \%$ & $\oplus \oplus \oplus \bigcirc^{*}$ \\
\hline 4 weeks & $80 / 572(14.0 \%)$ & $92 / 566(16.3 \%)$ & 0.87 (0.67 to 1.13 ) & 0.30 & $0 \%$ & $\oplus \oplus \oplus \bigcirc^{*}$ \\
\hline Any adverse events & $122 / 433(28.2 \%)$ & $108 / 418(25.8 \%)$ & 1.07 (0.89 to 1.29$)$ & 0.45 & $0 \%$ & $\oplus \oplus \oplus \bigcirc^{*}$ \\
\hline
\end{tabular}

$\mathrm{HCQ}$, hydroxychloroquine. RR, relative risk. $\mathrm{Cl}$, confidence interval.

Certainty: $\oplus$ very-low; $\oplus \oplus$ low; $\oplus \oplus \oplus$ moderate; $\oplus \oplus \oplus \oplus$ high .

* Risk of bias: not serious; Inconsistency: not serious; Indirectness: not serious; Imprecision: serious; Discrepancies in findings between peer-reviewed and non-peer reviewed publications:

no / not applicable; Influence of small trials (<100 patients per arm): no; Large effect: no. 
Table 5. Evidence synthesis on the safety of hydroxychloroquine for COVID-19 based on the results of blinded, placebo-controlled, randomized clinical trials.

\begin{tabular}{|c|c|c|c|c|c|}
\hline \multirow{2}{*}{ Adverse events } & \multicolumn{2}{|c|}{ Number of patients } & \multirow{2}{*}{$\operatorname{RR}(95 \% \mathrm{Cl})$} & \multirow{2}{*}{$\mathrm{p}$-value } & \multirow{2}{*}{$1^{2}$} \\
\hline & $\mathrm{HCQ}$ & Placebo & & & \\
\hline Any adverse events & $857 / 2896(29.6 \%)$ & $466 / 2350(19.8 \%)$ & $1.38(1.12$ to 1.71$)$ & $<0.01$ & $76 \%$ \\
\hline Serious adverse events & $38 / 1047$ (3.6\%) & $35 / 1060$ (3.3\%) & 1.07 (0.69 to 1.67 ) & 0.76 & $0 \%$ \\
\hline QTc interval $>500 \mathrm{~ms}$ & $18 / 359(5.0 \%)$ & $8 / 358(2.2 \%)$ & 2.13 (0.96 to 4.71$)$ & 0.06 & $0 \%$ \\
\hline Other cardiac manifestations & $58 / 706(8.2 \%)$ & $35 / 725(4.8 \%)$ & 1.52 (0.60 to 3.83 ) & 0.37 & $64 \%$ \\
\hline Gastrointestinal symptoms & $371 / 2222(16.7 \%)$ & $116 / 1764(6.6 \%)$ & 2.45 (1.77 to 3.39 ) & $<0.01$ & $58 \%$ \\
\hline Headache & $33 / 1357(2.4 \%)$ & $36 / 1288(2.8 \%)$ & 0.93 (0.55 to 1.56$)$ & 0.79 & $7 \%$ \\
\hline Skin rash & $37 / 1528(2.4 \%)$ & $25 / 1532(1.6 \%)$ & 1.46 (0.89 to 2.39 ) & 0.13 & $0 \%$ \\
\hline Neurologic reactions & 49/1461 (3.4\%) & $41 / 1471(2.8 \%)$ & 1.20 (0.80 to 1.78$)$ & 0.38 & $0 \%$ \\
\hline
\end{tabular}

$\mathrm{HCQ}$, hydroxychloroquine. RR, relative risk. $\mathrm{Cl}$, confidence interval. 